\title{
Classification of the Alaskan Beaufort Sea Coast and estimation of carbon and sediment inputs from coastal erosion
}

Received: 16 November 2003 / Accepted: 2 August 2004/Published online: 30 December 2004

(C) Springer-Verlag 2004

\begin{abstract}
A regional classification of shoreline segments along the Alaskan Beaufort Sea Coast was developed as the basis for quantifying coastal morphology, lithology, and carbon and mineral sediment fluxes. We delineated 48 mainland segments totaling $1,957 \mathrm{~km}$, as well as $1,334 \mathrm{~km}$ of spits and islands. Mainland coasts were grouped into five broad classes: exposed bluffs $(313 \mathrm{~km})$, bays and inlets $(235 \mathrm{~km})$, lagoons with barrier islands $(546 \mathrm{~km})$, tapped basins $(171 \mathrm{~km})$ and deltas $(691 \mathrm{~km})$. Sediments are mostly silts and sands, with occasional gravel, and bank heights generally are low (2-4 m), especially for deltas $(<1 \mathrm{~m})$. Mean annual erosion rates (MAER) by coastline type vary from $0.7 \mathrm{~m} /$ year (maximum $10.4 \mathrm{~m} /$ year) for lagoons to $2.4 \mathrm{~m} /$ year for exposed bluffs (maximum $16.7 \mathrm{~m} /$ year). MAERs are much higher in silty soils $(3.2 \mathrm{~m} /$ year $)$ than in sandy $(1.2 \mathrm{~m} /$ year) to gravelly $(-0.3 \mathrm{~m} /$ year) soils. Soil organic carbon along eroding shorelines (deltas excluded) range from 12 to $153 \mathrm{~kg} / \mathrm{m}^{2}$ of bank surface down to the water line. We assume carbon flux out from depositional delta sediments is negligible. Across the entire Alaskan Beaufort Sea Coast, estimated annual carbon input from eroding shorelines ranges from -47 to $818 \mathrm{Mg} / \mathrm{km} /$ year (Metric tones $/ \mathrm{km} /$ year) across the 48 segments, average $149 \mathrm{Mg} /$ $\mathrm{km} /$ year (for 34 nondeltaic segments), and total $1.8 \times 10^{5} \mathrm{Mg}$ /year. Annual mineral input from eroding shorelines ranges from $-1,863$ (accreting) to $15,752 \mathrm{Mg}$ /
\end{abstract}

M. T. Jorgenson ( $\square)$

ABR, Inc., PO Box 80410 ,

Fairbanks, 99708, AK, USA

E-mail: tjorgenson@abrinc.com

Tel.: + 1-907-4556777

Fax: +1-907-4556781

J. Brown

International Permafrost Association,

P.O. Box 7, Wood Hole, 02543, MA, USA

E-mail: jerrybrown@igc.org

Tel.: + 1-508-4574982

Fax: + 1-508-4574982 $\mathrm{km} /$ year, average $2,743 \mathrm{Mg} / \mathrm{km} /$ year, and totals 3.3 $\times 10^{6} \mathrm{Mg} /$ year.

\section{Introduction}

The Beaufort Sea Coast of northern Alaska extends from Pt. Barrow eastward to the Canadian border, a straight-line distance of $610 \mathrm{~km}$, and has $1,957 \mathrm{~km}$ of mainland coast. Three Inupiat towns with a population of $\sim 7,600$ and the Prudhoe Bay oil and gas facilities are located in the vicinity of the coastline. Despite the sea being frozen for 8-9 months of the year, annual coastal erosion rates of 2-4 m/year are common and are among the highest in the World (Reimnitz et al. 1988; Bird 2000). Carbon and sediment input from this coastal erosion provides a significant proportion of coastal carbon and sediment budgets (Rachold et al. 2000) and affects biological productivity and trophic-level dynamics (Schell 1983). As a contribution to the Arctic Coastal Dynamics (ACD) program (Rachold et al. 2002), which is developing circum-arctic estimates of erosional inputs to the inner continental shelf, this paper presents estimates of soil (particulate) organic carbon (SOC) and sediment inputs for the Alaskan Beaufort Sea portion of arctic coastline. In developing these estimates, we (1) classified and segmented the Beaufort Sea coastline, (2) to the extent possible summarized available information on erosion rates and sediment, SOC and ground ice contents by coastal segment, and (3) calculated SOC and mineral sediment inputs across the entire mainland coast of Alaska Beaufort Sea. These estimates are important for assessing how much carbon is released from longterm sequestration in permafrost, becomes bioavailable to marine ecosystems, and may be released to the atmosphere. How these processes and rates are affected by climate change, related to storm events, sea-ice retreat, and sea level rise, and their impacts on local communities and coastal industrial infrastructure, are all questions of concern for our continuing research. 
The Alaskan Beaufort Sea Coast is dominated by low, organic-rich, tundra bluffs faced by lagoons and barrier islands, exposed tundra bluffs without barrier islands, and deltas with or without barrier islands. Barnes et al. (1988) defined this coastal environment as extending from the $10-\mathrm{m}$ isobath inshore to the coast and inland for about $1 \mathrm{~km}$ in low-lying areas. Conceptually it consists of five zones: (1) floating fast ice, (2) bottom fast ice, (3) the gently sloping foreshore with reworked beach deposits, (4) the backshore face containing coastal plain sediments, deltas and fans and bedrock cliffs, and (5) terrain inland from the shoreline that is affected by storm surges and salinization. In this paper we focus solely on the backshore face (subaerial sediments) and avoid more problematic computation of the foreshore and nearshore zones with bottom fast ice. A considerable body of knowledge exists for the coastal zone of the Beaufort Sea, and we briefly summarize the significant findings below.

\section{Literature review}

Studies of coastal dynamics along the Alaska Beaufort Sea Coast were initiated by Leffingwell (1919) in his classic field investigations in northeastern Alaska in the early 1900s. He mapped the coastline and described the occurrences and formation of ice wedges in coastal bluffs. Since then numerous studies have reported on the rate of coastline retreat and aggradation. Measurements have been based on comparison of aerial photographs, navigation charts, actual measurements on the ground, and more recently using satellite imagery as base maps. Observations of erosion rates and beach processes in the Barrow region began in the late 1940s (MacCarthy 1953) and continued into the early 1980s (Harper 1978; Hume and Schalk 1967; Hume et al. 1972; Lewellen 1972, 1977; Walker 1991). A symposium volume on the coast and shelf of the Beaufort Sea (Reed and Sater 1974) reported on all aspects of the atmosphere-land-ice interactions including, ice scour, subsea permafrost, beach dynamics, and the runoff from the Colville River. Hartwell (1973) presented a four-part classification and a summary of elevations for both the Chukchi and Beaufort Coasts from Cape Thompson to the Canadian border. Reports by Hartz (1978), Hopkins and Hartz (1978), Reimnitz and Kempema (1987), Reimnitz et al. (1990), Short (1975), Short et al. (1974), Wiseman et al. (1973), and Woodward-Clyde Consultants (1981) provide descriptions of the coastal processes and morphology. Naidu and Mowatt (1975) produced a comprehensive study of deltaic sediments.

For the Elson Lagoon Coast southward to Dease Inlet (approximately $100 \mathrm{~km}$ ), Lewellen determined erosion rates using 1948/49 and 1962/64 aerial photography, and found rates typically were $1-3 \mathrm{~m} /$ year, but some rates as high as $10 \mathrm{~m} /$ year. Lewellen (1970) updated his earlier Elson Lagoon observations and extended them to Flaxman Island where erosion over a 30- year period averaged $3.5 \mathrm{~m} /$ year. Recent measurements from the long-term ACD observational key sites at Barrow (Brown et al. 2003; Manley 2004) in Elson Lagoon and from Beaufort Lagoon (Jorgenson et al. 2003b) in the Arctic National Wildlife Refuge found erosion rates of $0.7-2.8$ and $0.5-1.0 \mathrm{~m} /$ year, respectively. As a comparison for the Chukchi Sea Coast, Harper (1978) reported a mean rate of $0.3 \mathrm{~m} /$ year between 1949 and 1976 for the $75-\mathrm{km}$ coastline from Barrow to Peard Bay. Mackay (1986) reported annual erosion rates along the Canadian portion of the Beaufort Coastal Plain averaged $2.5 \mathrm{~m} /$ year (see also Hequette and Baernes 1990; Solomon and Gareau 2003).

The Outer Continental Shelf Environmental Assessment Program (OCSEAP) of the 1970s resulted in a large number of reports and publications. Several mapbased reports compared 1951 and 1983 navigation charts for $344 \mathrm{~km}$ of the central Beaufort Sea Coast (Reimnitz et al. 1988) and $304 \mathrm{~km}$ of the western coast (Barnes et al. 1992). The western third of the area, which is comprised of marine silts and sands, was reported to have substantially higher erosion rates $(5.4 \mathrm{~m} /$ year$)$. The remainder of the study area had a rate of $1.4 \mathrm{~m} / \mathrm{year}$, and is comprised of sandy to gravelly deposits (see also Naidu et al. 1984).

Reimnitz et al. (1988) and Barnes et al. (1992) were the first to estimate that the yield of Beaufort sediments from coastal erosion was six-fold greater than that contributed by the discharge from the adjacent river basins. Similar results have since been obtained for the Laptev Sea Coast (Grigoriev and Rachold 2003). In contrast, Macdonald et al (2003) calculated that the input of terrigenous particulate organic carbon (POC) from coastal erosion within the Colville delta was lower by a factor of 2 compared to the input from the Colville River, although their focus was on the POC balance within the delta and not to broader regional comparisons. A unique arctic process that contributes to riverine input is the fluvial deposition of sediments on shore-fast ice during spring breakup and subsequent redistribution by drifting ice floes (Naidu and Mowatt 1975).

\section{Regional setting}

The evolution of the coastal margin along the Beaufort Sea Coast is dependent on geomorphic, climatic, and oceanographic factors that provide the energy that control the erosion and deposition of materials across this highly dynamic transition zone. The origin of sediments along the coast is related in large part to the flat topography of the coastal plain in relation to the source areas in the upland watersheds and to a lesser extent to glacial outwash during periods of deglaciation (Rawlinson 1993). The North Slope of Alaska covers $230,000 \mathrm{~km}^{2}$ and slopes from the crest of the Brooks Range across the Brooks Foothills onto the unglaciated Beaufort Coastal Plain bordering the Arctic Ocean. The 
Coastal Plain is widest south of Barrow (approximately $150 \mathrm{~km}$ ) and narrows to the east. The 75-m topographic contour is generally taken as the boundary between the Coastal Plain and the Foothills. On the ocean side, the Beaufort Sea continental shelf is relatively narrow and is bordered to the west by the Barrow Canyon.

The coastal plain sediments consist of nearshore marine, glacio-fluvial, alluvial and eolian deposits of mid- to late-Quaternary age (Brown and Sellmann 1973). The nearshore marine sediments were deposited by a series of marine transgressions (Rawlinson 1993). Lacustrine processes also greatly modify coastal plain deposits by reworking and sorting surficial deposits, melting ground ice and creating large, oriented lake basins. Draining of lakes along the coast and rising sea levels have created large embayments. Numerous large rivers traverse the coastal plain and deposit finegrained sediments at the coast. The largest river, the Colville, originates in the foothills of the Brooks Range, drains $60,000 \mathrm{~km}^{2}$ and has a delta of $666 \mathrm{~km}^{2}$ (Walker 1976).

This entire land area is underlain by continuous permafrost with the exception of deep lakes and river channels. Ice-wedge polygons and shallow lakes dominate much of the low relief landforms bordering the coast. Permafrost extends to depths of $200-650 \mathrm{~m}$ beneath the land surface and at variable depths in offshore areas of sub-sea permafrost. Seasonal soil thaw (active layer) varies greatly from 20 to $30 \mathrm{~cm}$ in peats to an excess of a $1 \mathrm{~m}$ in sands. Ground ice typically occupies $60-80 \%$ of the volume of near-surface deposits (Brown and Sellmann 1973) and is a major factor in the high rates of erosion (Barnes et al. 1992).

The climate is characterized by $8-9$ month long winters and persistent winds. Mean annual air temperatures are similar across the arctic coast from Barrow $\left(-12.2^{\circ} \mathrm{C}\right)$ to Prudhoe Bay $\left(-11.3^{\circ} \mathrm{C}\right)$ and Barter Island $\left(-12.4^{\circ} \mathrm{C}\right)$. Mean annual wind speeds are slightly higher at Barrow $(5.7 \mathrm{~m} / \mathrm{s})$ than Barter Island $(4.8 \mathrm{~m} / \mathrm{s})$ (U.S. Weather Service data), although the frequency of strong winds is higher at Barter Island (Brower et al. 1988). Peak wind speeds at Barrow occur in October and November and most erosion appears to be associated with early fall storms during the ice-free period. Strongest winds typically are out of the east and northeast. For Barrow, the frequency of high-wind events decreased during the 1950s through the 1970s, and have increased through the 1980s and 1990s (Lynch et al. 2003; Brown et al. 2003). When comparing the frequency of strong winds ( $>22$ knots) in October, the frequency of strong winds at Barter Island $(14 \%)$ is more than double that at Barrow $(6 \%)$ (Brower et al. 1988).

The near-shore Beaufort Sea is ice covered most of the year with generally open water from mid-July to October. By early September, sea-ice retreats northward to $300-500 \mathrm{~km}$ offshore near Barrow and $100-300 \mathrm{~km}$ offshore at Barter Island. During the open-water season tides are on the order of $15 \mathrm{~cm}$. However, wind-driven waves during large storm events, can raise water levels as much as $2 \mathrm{~m}$, inundate low lying tundra for several kilometers inland, and increase erosion (Reimnitz and Maurer 1979; Kowalik 1984). These environmental parameters strongly influence erosion by creating sea ice and limiting the open-water period, and by the occurrence of strong winds when the extent of open water is greatest.

\section{Methods}

\section{Classification and segmentation}

Classification and segmentation of the coastline between Point Barrow and the Canadian border involved differentiating segments with differing wave exposure (with or without barrier islands), shoreline sinuosity, lithology (silt, sand, gravel), bank height, and erosion rates, and erosional/depositional characteristics. The range of characteristics was grouped into five main classes for data analysis, exposed bluffs, lagoons (with barrier islands), bays and inlets, tapped basins, and deltas. The world vector shoreline (WVS), which is a digital data file at a nominal scale of 1:250,000 that contains the shorelines, international boundaries and country names of the world, was used as the base map to compute segment lengths. Segmentation was done in ArcView and each segment was labeled with a segment number, segment name, lithology (soil texture), and geomorphic unit (genetic origin). The WVS was overlaid on georectified Landsat imagery and the imagery was used to aid interpretation of shoreline characteristics. The lithology and geomorphic information obtained from Naidu and Mowatt (1975), Walker (1976, 1983), Carter and Galloway (1985), Carter et al. (1986), Rawlinson (1993), Jorgenson et al. (1997, 2003a, b) was also used to established breaks in shoreline soil characteristics. For two sectors between Drew Point and the Canadian Border, the segmentation was generally similar to those designated by Reimnitz et al. (1988) and Barnes et al. (1992). Offshore islands and barrier spits were not included as they were not considered for this study a source of organic carbon.

We also compared our regional classification to the large-scale classification and segmentation of the coastline recently completed under contract to the U.S. Mineral Management Service (MMS) in Anchorage, AK (Research Planning Inc 2002). This classification for the environmental sensitivity index (ESI) mapping was based on a classification of shoreline types according to a standard ranking scheme based primarily on sediment texture that has been applied throughout the United States, although the classification was modified for the northern Alaskan environment. Each local segment from the ESI map was labeled with the name of our corresponding regional segment. The ESI segments were then cross tabulated with our regional segments to characterize the composition of our regional segments 
and to provide a comparison of shoreline lengths generated from the two scales.

\section{Data compilation and parameterization}

Regional data on coastal erosion rates for large portions of the coastline from Point Barrow to the Demarcation Bay were compiled from Lewellen (1972), Reimnitz et al. (1988) and Barnes et al. (1992). Data from more localized sites were compiled from: (1) Elson Lagoon by MacCarthy (1953), Hume et al. (1972), and Brown et al. (2003); (2) Cape Halkett by Kovacs (1983); (3) Colville Delta by Walker $(1976,1983)$ and Jorgenson et al. (1997); (4) Simpson Lagoon and Prudhoe Bay by Dygas et al. (1972), Cannon and Rawlinson (1981), and Naidu et al. (1984); (5) Flaxman Island by Lewellen (1970); (6) Canning River area by Leffingwell (1919); (7) Beaufort Lagoon (Jorgenson et al. 2003b).

Ground ice measurements for both ice wedges and segregated ice were available for very few areas. The volume of ice wedges near the surface was obtained from estimates near Elson Lagoon (Brown 1968; Sellmann et al. 1975), and using the data developed from the Flaxman Island (Leffingwell 1919), and the Colville Delta (Jorgenson et al. 1997). These few observations were extrapolated to other coastal segments based on similarity of soil texture and geomorphic units. Based on the results from Jorgenson et al. (1997), we assigned a value of $20 \%$ for the volume of near-surface ice (immediately below the active layer) in the soil of older, higher shorelines with high density ice-wedge polygons, a value of $10 \%$ to areas dominated by old drained basins, and $1 \%$ to areas dominated by younger deposits (e.g. deltas).

Soil organic carbon (SOC) and mineral sediment densities (based on frozen core volumes) also were available only from a few areas along the coast. For the Elson Lagoon Coast, carbon values for the upper $1 \mathrm{~m}$ in silty sediments were obtained from Bockheim et al. $(1999,2002)$. For the area for the Fish Creek Coast and the Colville Delta, SOC values for the top $2-3 \mathrm{~m}$ of eolian sands and pebbly silty sands (e.g. Beechey Sands as described by Rawlinson 1993) were obtained from Jorgenson et al. (2003a). At Beaufort Lagoon, organic carbon values for depths up to $3.3 \mathrm{~m}$ in silty and pebbly silt sands in the backshore were obtained from Jorgenson et al. (2003b).

\section{Carbon and mineral input computations}

Soil organic carbon and mineral sediment profiles were calculated for lithologies dominated by silt (e.g. marine silts), pebbly silty sands (e.g. Beechey sands), and clean sands (eolian sand dunes). For each 1-m increment, the carbon and inorganic sediment masses were calculated:

$$
\begin{aligned}
& M_{\mathrm{c}}=\sum_{i-j} \rho_{\mathrm{b}} \times\left(h \times \mathrm{cm}^{2} \times 10^{5}\right) \times \% \mathrm{C} \\
& M_{\mathrm{m}}=\sum_{i-j}\left(\rho_{\mathrm{b}} \times\left(h \times \mathrm{cm}^{2} \times 10^{5}\right)\right)-M_{\mathrm{c}}
\end{aligned}
$$

Where $M_{c}$ is mass of total SOC $\left(\mathrm{kg} / \mathrm{m}^{3}\right) ; M_{m}$ is mass of mineral sediment $\left(\mathrm{kg} / \mathrm{m}^{3}\right) ; \rho_{b}$ - dry bulk density $\left(\mathrm{g} / \mathrm{cm}^{3}\right)$ based on volume of the original frozen sample; $\% \mathrm{C}$-percent carbon (including carbonates which average $0.3 \%$ ) determined with a LECO $1000 \mathrm{CHN}$ analyzer and $h$-thickness of individual layer $(\mathrm{cm})$. After $M_{c}$ is calculated each layer $(i-j)$ in the core, the $M_{c}$ results from each layer are summed within each $1-\mathrm{m}$ increment and then by entire core. By working directly with dry density profiles, the mass estimates inherently account for the reduction in carbon and mineral mass due to the presence of segregated ice. Once cumulative carbon and mass profiles were developed from the various profiles by texture, average values for each $1-\mathrm{m}$ increment were determined across profiles with similar texture.

Mean annual inputs of the SOC and mineral sediments from coastal erosion were calculated from the data on mean annual erosion rates, backshore elevation, ice-wedge volume, and carbon and sediment masses for each $1-\mathrm{m}$ increment. To account for the changes in ice volume with depth, ice-wedge volume was assumed to be $0 \%$ for the top $0.5 \mathrm{~m}$ (average active layer), $100 \%$ of the near-surface volume occupied by ice wedges at $0.5-2 \mathrm{~m}$, $50 \%$ of the near-surface volume at $2-3 \mathrm{~m}$, and $10 \%$ of near-surface volume below $3 \mathrm{~m}$. The carbon and sediment masses for each increment then were reduced by the volume percentages described above. The total SOC and mineral mass in the profile per square meter of ground surface from sea level to the backshore elevation (bank height) was the sum of the 1-m increments (or fraction of 1-m increment for the bottom segment) after reduction for ice volume. The mean annual input per kilometer of shoreline $(\mathrm{Mg} / \mathrm{km} /$ year $)$ was calculated as bank profile mass $\left(\mathrm{kg} / \mathrm{m}^{2}\right) \times$ mean annual erosion rate $(\mathrm{m} /$ year $) \times 1,000 \mathrm{~m}$ of shoreline. The input per segment ( $\mathrm{Mg}$ or metric ton) was calculated as $\mathrm{Mg} / \mathrm{km}$ of shoreline $\times$ segment length $(\mathrm{km})$. For this report we did not compute the nearshore contribution of sediment input due to the limited information on offshore morphology and erosion rates, ground-ice content, permafrost degradation and sediment transport, although nearshore computations have been done by Reimnitz et al. (1988).

\section{Results}

Classification and segmentation

The mainland coast of the Alaskan Beaufort Sea was subdivided into 48 segments totaling $1,957 \mathrm{~km}$, with an additional 1,334 km of spits and islands (Fig. 1, Table 1). At this regional scale, mainland coasts were grouped into five broad classes, exposed bluffs $(313 \mathrm{~km})$, 

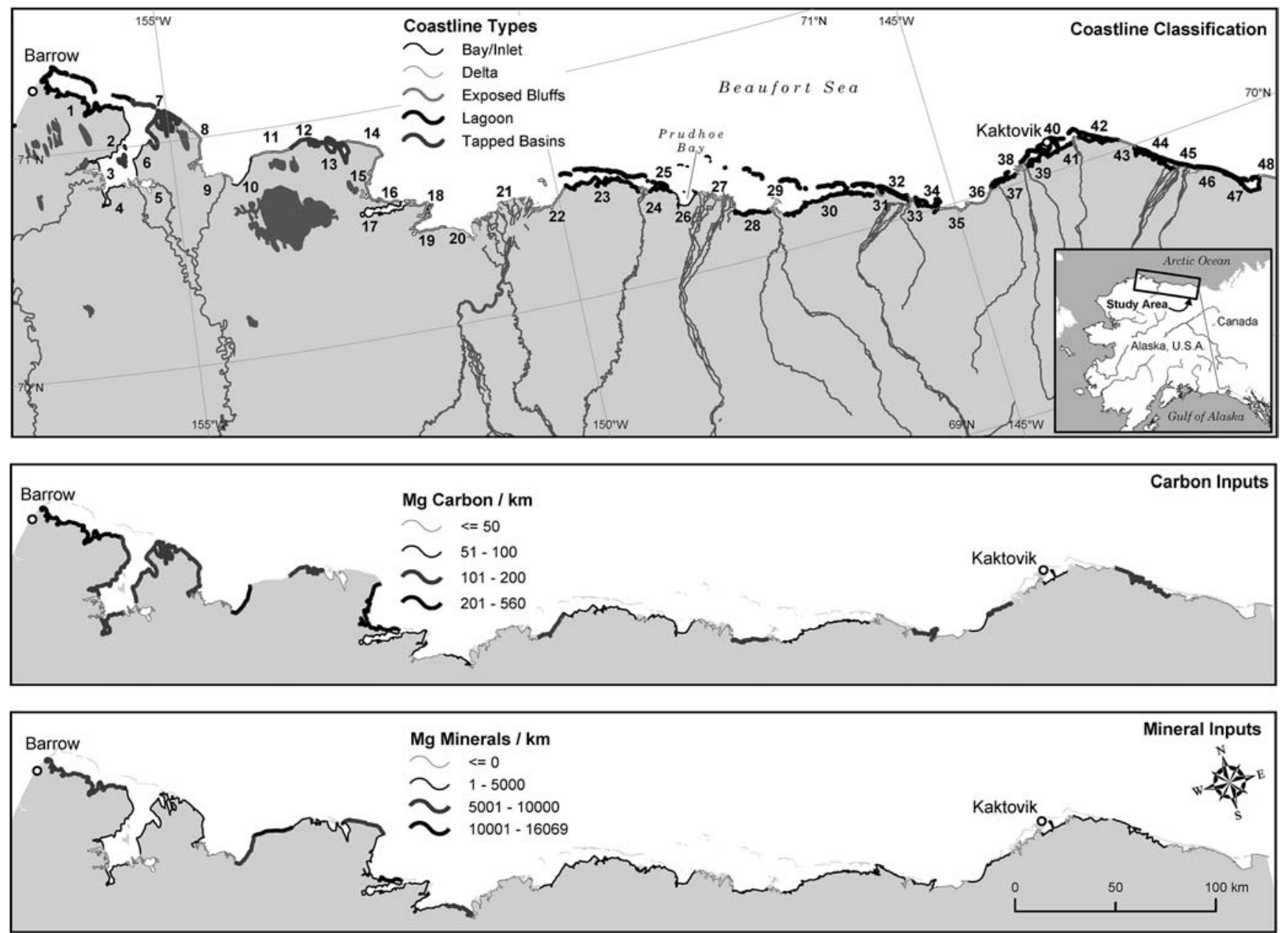

Fig. 1 Distribution of coastline types (top), soil organic carbon inputs (middle), and mineral sediment inputs (bottom) associated with 48 regional segments along the Beaufort Sea coast from Barrow to the Canadian border. Refer to Table 1 for segment names and shoreline characteristics

lagoons with barrier islands $(546 \mathrm{~km})$, bays and inlets $(235 \mathrm{~km})$, tapped basins $(171 \mathrm{~km})$ and deltas $(691 \mathrm{~km})$. For comparison, the length of the mainland coast from the Alaska E-Series map (1:2,500,000 scale) was $1,783 \mathrm{~km}$, with the difference mainly due to how deltaic coasts were delineated. In contrast, larger-scale $(1: 63,000)$ mapping for NOAA's environmental sensitivity index maps delineated 5,037 segments totaling $4,903 \mathrm{~km}$ (mainland coast and islands). Two large islands that are remnant coastal plain deposits, Flaxman $(19 \mathrm{~km})$ and Barter Islands $(35 \mathrm{~km})$, have erosion similar to the mainland, but they were not included in the analysis because much of their shoreline length is comprised of gravel spits, and erosion and sedimentation on the landward side is problematic. The five general shoreline types are described below.

Exposed bluffs occur primarily along the western and eastern portion of the study area (Fig. 2). Bank heights typically are $2-4 \mathrm{~m}$ and lithology varies from very icerich, predominantly reworked marine silt along the western coast (Segment 1-Elson Lagoon to 15-Cape Halkett East Coast), to ice-poor sands in eolian deposits along the central coast (19-Fish Creek Coast), to moderately ice-rich pebbly silty sand (Beechey Sands according to Rawlinson 1993) along the central to eastern coast (22-Oliktok Coast to 47-Demarcation Bay) (Fig. 3). Ice wedges are estimated to occupy $\sim 20 \%$ by volume of the upper permafrost in the higher, early Holocene to late Pleistocene deposits. Exposed bluffs have the highest mean annual erosion rates across all segments $(2.4 \mathrm{~m} / \mathrm{year})$, the highest rates for any segment $(8.3 \mathrm{~m} /$ year at 11 -Drew Point Coast), and highest rate for any individual point (16.7 m/year at 14-Cape Halkett North Coast) occurred on this coastal type. Low peaty shorelines with underlying lacustrine sediments occur where lakes have been drained by erosion of the bluff.

Deep bays and inlets (e.g., 2-Dease Inlet Coast West) are most common in the western portion of the coast, which is comprised of ice-rich marine silt. They typically formed from coalescence of large lakes that have been breached and flooded by seawater or from flooding of old floodplains during sea level rise during the mid-late Holocene. Bank heights generally are $2-3 \mathrm{~m}$ and ice-wedge volumes are assumed to be similar to those described for exposed bluffs. The mean annual 


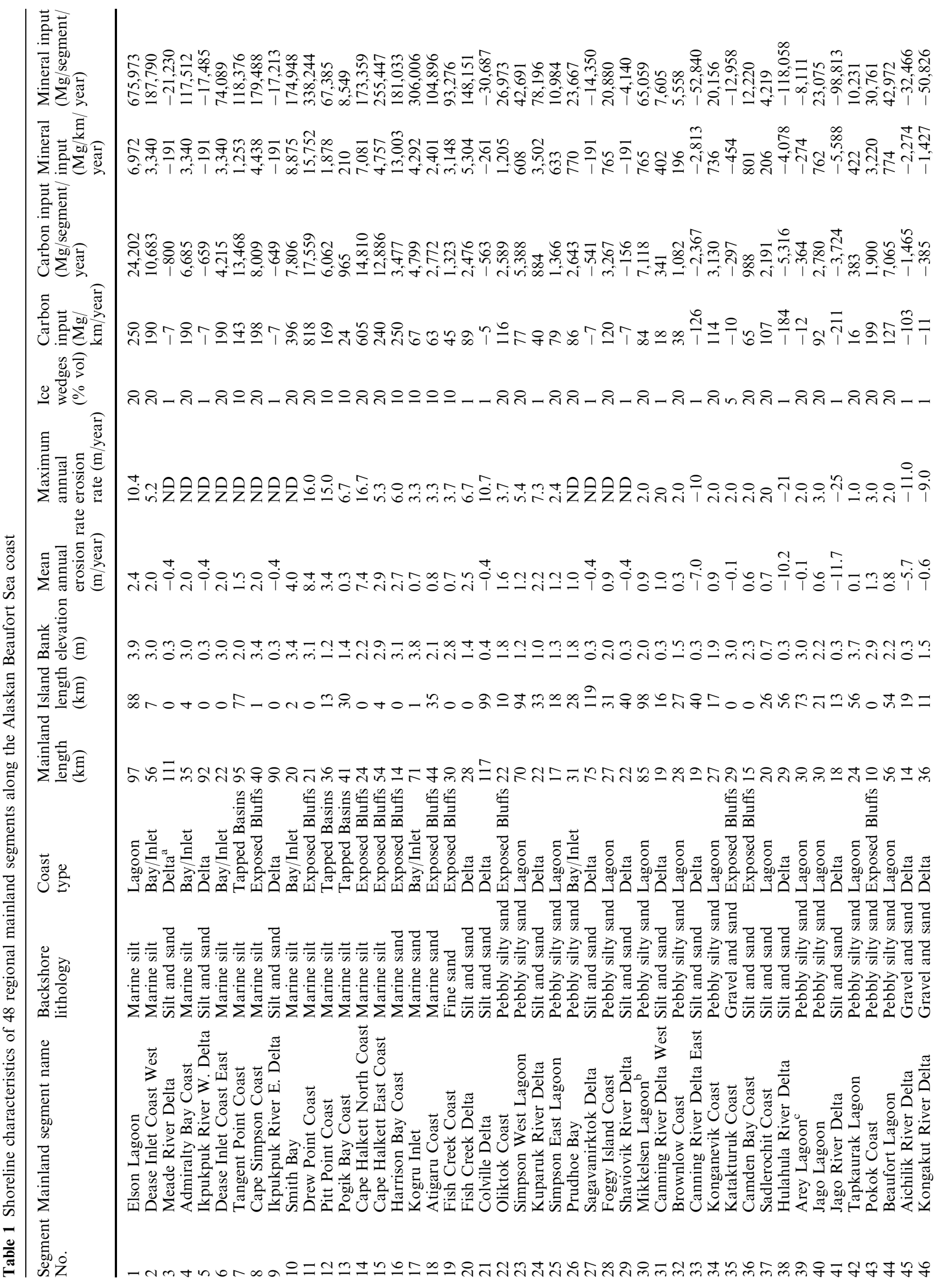


erosion rate $(2.0 \mathrm{~m} /$ year $)$ for this coastal type is slightly less than that for exposed bluffs, presumably because of the larger available fetch distance across the large bays.

Tapped basins occur in extremely ice-rich marine silts found in the western portion of the area (7-Tangent Point Coast to 13-Pogik Bay Coast). Thaw lakes in this area are unusually large, due to the low relief, Sellmann et al. (1975), and occasionally breached by the sea as erosion proceeds landward. Observations are only available for small segments along the outer coast, thus little is known about erosion rates along the majority of the shoreline comprising inland tapped lakes. We estimated ice-wedge volume to average $10 \%$, although ice volumes probably are highly variable from $<1 \%$ in recently tapped basins to $20 \%$ in the older higher surfaces. For reasons stated, our estimates of erosion rates $(1.7 \mathrm{~m} /$ year) are relatively unreliable for this shoreline type.

Lagoons with barrier islands are prevalent along the coast and the mainland portion of this type is similar to that for exposed bluffs. The lagoons are bordered seaward by barrier islands and spits which protect the lagoons and bluffs from storm generated, high waves. Most barrier islands are sandy, and occasionally gravelly. Lagoons generally have water depths of 2-4 m, which reduce wave heights. Mean annual erosion rates $(0.7 \mathrm{~m} /$ year $)$ for this coastal type are the lowest for any type, except deltas.

Large and small deltas are found across the entire study area, with the Colville Delta being the largest and best studied (Naidu and Mowatt 1975; Walker 1976; Jorgenson et al. 1997). Localized sediment accumulation can be rapid (10 $\mathrm{cm}$ or more) after large breakup or precipitation events (Walker 1976). During spring breakup much of the sediment is deposited on land-fast ice and carried offshore by dispersing ice floes. Shoreline slopes are very gentle in deltaic environments with the ground elevation near mean sea level at the waters edge and gently rising to $0.5-1 \mathrm{~m}$ over a distance of several kilometers (Fig. 3). Because deltas are formed by a network of distributaries, the total length of shoreline can be large. Ice contents and carbon contents are low due to the rapid accumulation of sediments. We did not estimate carbon and sediment accumulation rates for deltaic environments because of the imprecision in estimating sediment accumulation from photogrammetric measurements of shoreline changes, and the highly sinuous shoreline with highly variable erosional and depositional rates. For the Colville Delta, Naidu et al. (1999), however, estimated sedimentation rates of $1 \mathrm{~kg}$ / $\mathrm{m}^{2} / \mathrm{yr}$ for nearshore areas.

\section{Carbon and sediment inputs}

We estimate that SOC in bank profiles (sub aerial sediments) range from $12 \mathrm{~kg} / \mathrm{m}^{2}$ in deltaic sediments (tidal flats) to as high as $153 \mathrm{~kg} / \mathrm{m}^{2}$ in lagoon-facing bluffs (Table 1). Cumulative SOC and mineral mass of repre- 
Fig. 2 Landsat images of five coastline types along the Alaska Beaufort Sea Coast, including exposed bluffs along Drew Point Coast (upper left, Segment 11) and Pokok Coast (upper right, Seg. 43), tapped basins along Tangent Point Coast (middle left, Seg. 7), bay/ inlet at Smith Bay (middle right, Seg. 10), lagoons along Elson Lagoon (lower left, Seg. 1), and deltas such as the Colville Delta (lower right, Seg. 21)
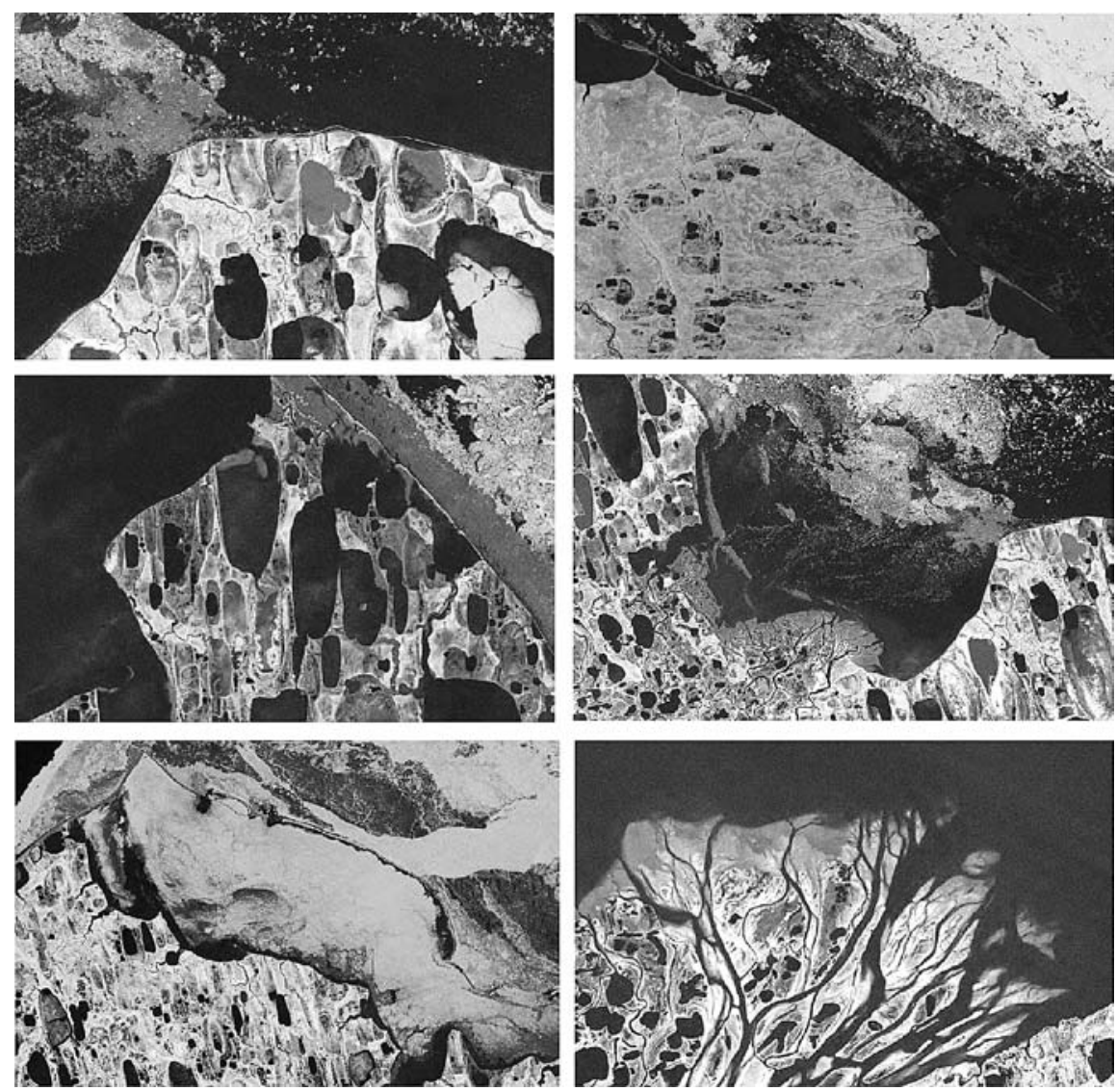

sentative profiles vary widely depending on whether lithology is dominated by silt, pebbly silty sand, or sand. Estimates of mean annual SOC inputs from erosional mainland coastal types (deltas excluded) range from -47 to $818 \mathrm{Mg} / \mathrm{km} /$ year (metric tonnes) of shoreline and average $149 \mathrm{Mg} / \mathrm{km} /$ year of shoreline across all 34 non deltaic segments (Table 2). Total mean annual carbon input across the entire Alaskan Beaufort Sea Coast is estimated at $1.8 \times 10^{5} \mathrm{Mg} /$ year based on estimates for erosional mainland coastal types $(1,265 \mathrm{~km})$ and the assumption that the input from deltaic depositional environments $(691 \mathrm{~km})$ is negligible.

Mineral sediments in bank profiles range from $295 \mathrm{~kg} / \mathrm{m}^{2}$ in low banks with ice-rich materials to as high as $5,962 \mathrm{~kg} / \mathrm{m}^{2}$ in ice-poor alluvial sediments in high banks. Estimates of mean annual mineral inputs from erosional mainland coastal types (deltas excluded) range from $-1,863 \mathrm{Mg} / \mathrm{km} /$ year of shoreline in Demarcation Bay (Seg. 47) with both eroding and accreting shorelines to $15,752 \mathrm{Mg} / \mathrm{km}$ of shoreline along the Drew Point Coast (11), which has high erosion rates. The mean annual mineral input across all segments is estimated to be $2,743 \mathrm{Mg} / \mathrm{km} /$ year of shoreline (Table 2). Total mean annual mineral input across the entire study area is estimated at $3.3 \times 10^{6} \mathrm{Mg} /$ year.

Coastline type and soil texture were both found to be important factors affecting erosion. Highest mean annual erosion rates occur in exposed bluffs with high fetch lengths (100-300 $\mathrm{km}$ at minimum sea ice extent) and lowest in lagoons protected by barrier islands (Fig. 4, Table 2). Higher erosion rates also occur in silty compared to gravelly substrates. When coastline types are grouped, the highest mean annual rates occur along silty shorelines that are exposed to the open ocean $(5.2 \mathrm{~m} /$ year) and lowest along lagoons with gravelly shorelines $(-0.5 \mathrm{~m} /$ year, accreting). Shoreline morphology also is related to these material types and erosion rates. The ice-rich silty bluffs lack a protective beach and erosion is dominated by the collapse of undercut blocks from the bank (Fig. 3). In contrast, pebbly silt sands and gravel shorelines develop relatively wide beaches armored by lag gravel layers at the surface. Wave energy in the latter beaches is dissipated on the beach and removal of material from the backshore is much slower. In contrast, the nearly flat, outer deltaic deposits generally lack steep backshores to be eroded and are primarily depositional environments.

\section{Discussion}

These estimates of mean annual SOC and mineral sediment inputs from erosion provide the first approximation of terrigenous inputs for the entire Alaskan Beaufort Sea Coast. While the estimates are based on limited data and required extensive extrapolation among 

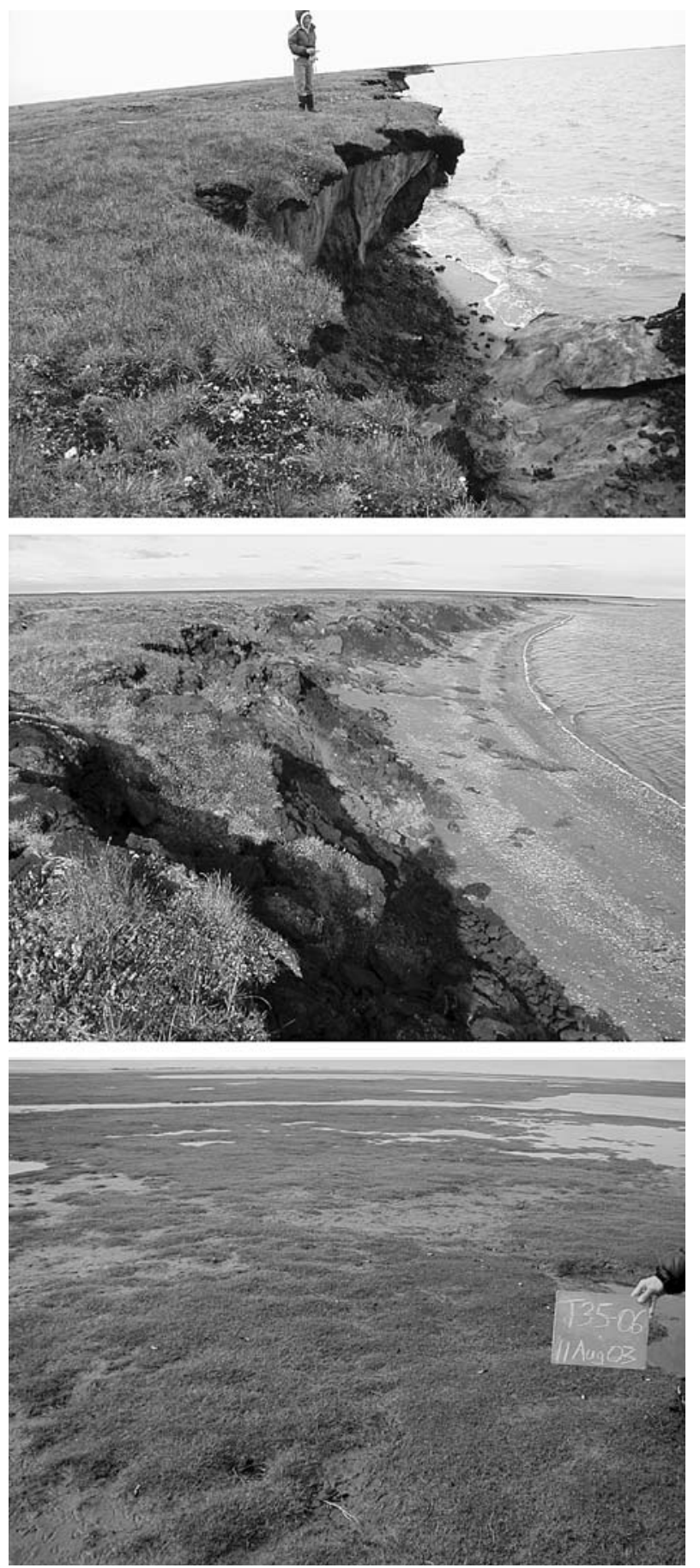

Fig. 3 Coastline morphology has a large effect on erosion rates. Highest rates were found on steep, silty bluffs that lack beaches (top, photo by Jim Bockheim), intermediate for bluffs with a broad, gravelly foreshore (middle), and lowest for flat, silty deltaic environments (bottom)

segments, results from this regional computational approach are in the same range as those obtained from local studies. For a small portion of Elson Lagoon (Seg. 1), Brown et al. (2003) estimated mean annual SOC inputs from erosion along the coastline to be lower $(63 \mathrm{Mg} / \mathrm{km} /$ year) than what we estimate for the entire

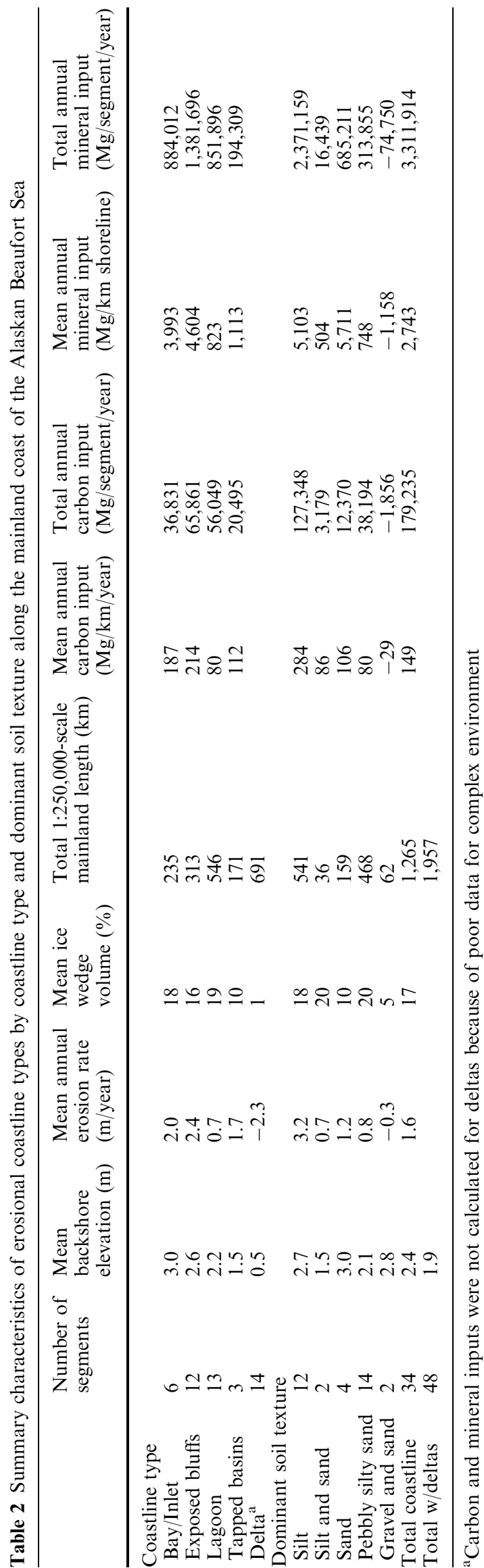


Fig. 4 Mean annual erosion rates (averaged by segment) by soil texture and coastline type for the mainland coast of the Alaskan Beaufort Sea

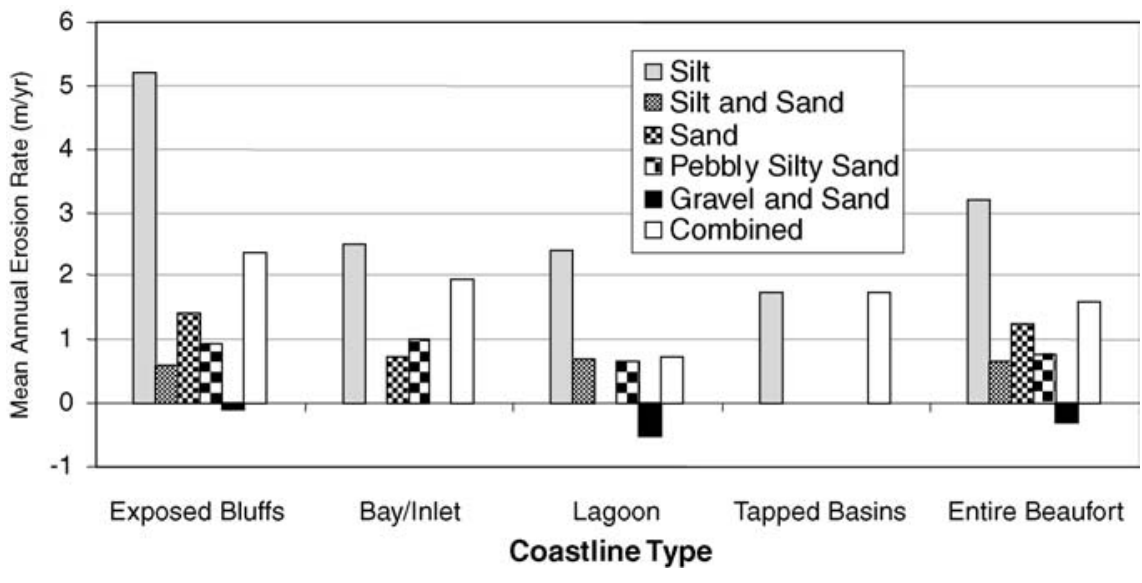

segment (219 Mg/km/year). However, the previous estimate was based on only the upper $1 \mathrm{~m}$ and had lower erosion rates than what we used for carbon estimates for the regional segment (Seg. 1). For a small portion of Beaufort Lagoon (Seg. 44), Jorgenson et al. (2003b) estimated mean annual SOC inputs from erosion that were only slightly lower (38-68 Mg/ $\mathrm{km} /$ year) than what we estimate for the entire segment $(88 \mathrm{Mg} / \mathrm{km} /$ year $)$. While our calculations were based on limited available data, our values for the upper $1 \mathrm{~m}\left(30-79 \mathrm{~kg} / \mathrm{m}^{2}\right)$ were similar to the values of $59-94 \mathrm{~kg} / \mathrm{m}^{2}$ reported by Ping et al. (2002) near Segment 26 , and $42-58 \mathrm{~kg} / \mathrm{m}^{2}$ by Hinkel et al. (2003) and $18-60 \mathrm{~kg} / \mathrm{m}^{2}$ by Bockheim et al. (2002) in Segment 1. When comparing our estimate to the larger Arctic Ocean, the Alaskan Beaufort Sea Coast contributes $3 \%$ of the terrigenous organic input, based on a rough estimate of SOC flux $\left(6.8 \times 10^{6} \mathrm{Mg} / \mathrm{km} /\right.$ year $)$ into the entire Arctic Ocean from coastal erosion by Grigoriev and Rachold (2003).

Our estimates for the average erosional inputs for mineral sediments $(2,743 \mathrm{Mg} / \mathrm{km} /$ year of shoreline $)$ across the eroding shorelines are less than half of the values $(6,600 \mathrm{Mg} / \mathrm{km}$ of shoreline) reported by Reimnitz et al. (1988) for $344 \mathrm{~km}$ of coast from Drew Point to Prudhoe Bay. We attribute the difference between Reimnitz's and our values for the Beaufort Sea Coast to lower erosion rates in the eastern portion of the study area which has sandier sediments, to more precise accounting of SOC contents, dry bulk densities, and ground ice through the bank profiles in our approach, and to differences in computational methods. Also, note erosion and deposition of islands and spits were not included in our study. In other comparisons, Cannon and Rawlinson (1981) estimated the mean annual input of coastal erosion at Simpson Lagoon to be $6.8 \times 10^{5} \mathrm{Mg} / \mathrm{km} /$ year for peaty soil and $4.5 \times 10^{6} \mathrm{Mg} / \mathrm{km} /$ year for inorganic sediments. Hill et al. (1991) estimated mean annual sediment input into the Canadian portion of the Beaufort Sea Coast to be $5.6 \times 10^{5} \mathrm{Mg} / \mathrm{km} /$ year and total $5.6 \times 10^{6} \mathrm{Mg} /$ year for the entire $1,150 \mathrm{~km}$ of coast. Grigoriev and Rachold (2003) estimated mean annual inputs for the Laptev Sea Coast to be $11 \times 10^{5} \mathrm{Mg} / \mathrm{km} /$ year and total $58.4 \times 10^{6} \mathrm{Mg} /$ year for the entire $2,400 \mathrm{~km}$ of coast.
While the classification and segmentation of the coast provides only a rudimentary method for estimating inputs from coastal erosion, the lack of in situ data prevents more accurate calculations. Information on bank heights and erosion rates are sufficient to adequately parameterize most segments, but data on carbon, mineral, and ice contents are absent from nearly all segments and required assigning values from a few segments to most of the others based on lithology. Given the high data requirements needed to improve estimates of carbon and mineral inputs from the regional segmentation approach, we suggest that an alternative method of randomly or systematically sampling 30-50 sites across the study area irrespective of coastline conditions would provide a cost-effective approach for improving the accuracy of estimating erosional inputs from the study area.

\section{Conclusions}

Our calculations provide a first approximation of the mean annual input of soil organic carbon and mineral sediment mass across the entire Alaskan Beaufort Sea Coast based on a regional classification and segmentation approach and available soils data. The 1,957-km shoreline from Point Barrow to the Canadian border was classified into five shoreline types and divided into 48 segments to partition the variability in coastal morphology, bank lithology, bank height, ice-wedge volume, erosion rates, and erosional/depositional characteristics. Based on limited available data, we estimate that the mean annual SOC input from erosional mainland coastal types (deltas excluded) ranges from -47 to $818 \mathrm{Mg} / \mathrm{km} /$ year of shoreline, averages $149 \mathrm{Mg} / \mathrm{km} /$ year of shoreline across 34 erosion segments, and totals $1.8 \times 10^{5} \mathrm{Mg} /$ year for the entire Alaskan Beaufort Sea Coast (assuming input from 14 delta segments is negligible). Estimated mean annual mineral input from erosional mainland coastal types ranges from $-1,863 \mathrm{Mg} /$ $\mathrm{km}$ (accreting) to $15,752 \mathrm{Mg} / \mathrm{km}$ of shoreline, average $2,743 \mathrm{Mg} / \mathrm{km}$ of shoreline, and totals $3.3 \times 10^{6} \mathrm{Mg}$. These estimates will contribute to efforts by the ACD program to estimate organic carbon and mineral sediment inputs 
to the entire Arctic Ocean from the relatively rapid coastal erosion that occurs along these ice-rich, permafrost-dominated shorelines.

Acknowledgments The following individuals collaborated in the investigations: Orson Smith and William Lee University of Alaska Anchorage; Craig Tweedie, Michigan State University; and James Bockheim, University of Wisconsin for the Barrow area. Janet C. Jorgenson, U.S. Fish and Wildlife Service; Chien-Lu Ping and Yuri Shur, University of Alaska Fairbanks; Jennifer Harden; U.S. Geological Survey for the Beaufort sites. Matt Macander, ABR, Inc. assisted on photogrammetric analyses and GIS analyses. The Fish and Wildlife Service provided financial and logistical support at Beaufort Lagoon. Some of the soil data was provided by projects funded by ConocoPhillips, Inc., Anchorage, Alaska. The Barrow Arctic Science Consortium under several cooperative agreements with the National Science Foundation provided support at Barrow through the able assistance of Dave Ramey and Matt Irinaga. The U.S. Minerals Management Service, Anchorage, provided the ESI segmentation information. We appreciated the helpful reviews by Sathy Naidu and H. J. Walker.

\section{References}

Barnes PW, Rawlinson SE, Reimnitz E (1988) Coastal geomorphology of Arctic Alaska. Arctic coastal practices and slope protection design, TCCR Practice Report. ASCE, pp 3-29

Barnes PW, Reimnitz E, Rollyson BP (1992) Map showing Beaufort Sea coastal erosion and accretion between Flaxman Island and the Canadian border northeastern Alaska, $(1: 82,000)$. US Geol Surv Misc Invest Ser Map I-1182-H, p 22

Bird, ECF (2000) Coastal geomorphology: an introduction. Wiley, New York, p 322

Bockheim JG, Everett LR, Hinkel KM, Nelson FE, Brown, J (1999) Soil organic carbon storage and distribution in arctic tundra, Barrow, Alaska. Soil Sci Soc Am J 63:934-940

Bockheim JG, Hinkel KM, Nelson FE (2002) Soils of the Barrow region, Alaska. Polar Geogr 25:163-171

Brower WA, Baldwin, RG, Williams CN, Wise JL, Leslie LD (1988) Climatic atlas of the outer continental shelf waters and coastal regions of Alaska University of Alaska, Anchorage

Brown J (1968) An estimation of the volume of ground ice, coastal plain, northern Alaska. US Army CRREL Tech Note, p 22

Brown J, Sellmann PV (1973) Permafrost and coastal plain history, Arctic Alaska. In Alaskan Arctic Tundra. Arctic Institute of North America, Technical Paper No. 25, pp 31-47

Brown J, Jorgenson MT, Smith OP, Lee W (2003) Long-term rates of erosion and carbon input, Elson Lagoon, Barrow, Alaska. In: Phillips M, Springman SM, Arenson, LU (eds), ICOP 2003 Permafrost: Proceedings of the 8th International Conference on Permafrost. AA Balkema Publishers, Netherlands, pp 101-106

Cannon PJ, Rawlinson SE (1981) Environmental geology and geomorphology of the barrier island-lagoon system along the Beaufort Sea Coastal Plain from Prudhoe Bay to the Colville River. Outer Continental Shelf Environmental Assessment Program. National Oceanic and Atmospheric Administration. Final Report of Principal Investigators 34:357-444

Carter LD, Galloway JP (1985) Engineering-geologic maps of northern Alaska, Harrison Bay quadrangle: US Geol Surv Open File Rep 85-256, p 47

Carter LD, Ferrians OJ, Galloway JP (1986) Engineering-geologic maps of northern Alaska, coastal plain and foothills of the Arctic National Wildlife Refuge. US Geol Surv Open File Rep 86-334

Dygas JA, Tucker R, Burrell DC (1972) Geologic report of the heavy minerals, sediment transport, and shoreline changes of the barrier islands and coast between Oliktok Point and Beechey Point. In: Kinney, PJ et al. (eds) Baseline study of the Alaskan Arctic aquatic environment. Institute of Marine Science, University of Alaska. Rep R72-3, pp 62-121
Grigoriev MN, Rachold V (2003) The degradation of coastal permafrost and the organic carbon balance of the Laptev and East Siberian Seas. In: Phillips M, Springman SM, Arenson LU (eds) Permafrost: Proceedings of the Eighth International Conference on Permafrost. AA Balkema Publishers, Netherlands, pp 319324

Harper JR (1978) Coastal erosion rates along the Chukchi Sea coast near Barrow, Alaska. Arctic 31:428-433

Hartwell AD (1973) Classification and relief characteristics of northern Alaska's coastal zone. Arctic 26:244-252

Hartz RW (1978) Erosional hazards map of the arctic coast of the National Petroleum Reserve Alaska. US Geol Surv Wash Open File Report 78-406, p 8

Hequette A, Barnes PW (1990) Coastal retreat and shoreface profile variations in the Canadian Beaufort Sea. Mar Geol 91:113-132

Hill PR, Blasco SM, Harper JR, Fissel DB (1991) Sedimentation on the Canadian Beaufort Shelf. Continental Shelf Res 11:821842

Hinkel KM, Eisner WE, Bockheim JG, Nelson FE, Peterson KM, Xiaoyan D (2003) Spatial extent, age, and carbon stocks in drained thaw lake basins on the Barrow Peninsula, Alaska. Arctic Antarctic Alpine Res 35:291-300

Hopkins DM, Hartz RW (1978) Coastal morphology, coastal erosion, and barrier islands of the Beaufort Sea, Alaska. US Geol Surv Open File Rep 78-1063, p 54

Hume JD, Schalk M (1967) Shoreline processes near Barrow, Alaska. Arctic 20:86-103

Hume JD, Schalk M, Hume PW (1972) Short-term climate changes and coastal erosion, Barrow, Alaska. Arctic 25:272-278

Jorgenson MT, Pullman, ER, Shur YL (2003a) Geomorphology of the Northeast Planning Area of the National Petroleum Reserve-Alaska, 2002. Unpublished Report prepared for ConocoPhillips Alaska, Inc. Anchorage, $\mathrm{AK}$ by $\mathrm{ABR}$, Inc., Fairbanks p 67

Jorgenson MT, Macander M, Jorgenson JC, Ping CL, Harden J (2003b) Ground ice and carbon characteristics of eroding coastal permafrost at Beaufort Lagoon, northern Alaska. In: Phillips M, Springman SM, Arenson LU (eds) ICOP 2003 Permafrost: Proceedings of the 8th International Conference on Permafrost. AA Balkema Publishers, Netherlands, pp 495-500

Jorgenson MT, Pullman ER, Zimmer T, Shur YL, Stickney AA, Li S (1997) Geomorphology and hydrology of the Colville River Delta, Alaska, 1996. Unpublished Report prepared for ARCO Alaska, Inc., Anchorage, AK by ABR, Inc., Fairbanks, p 148

Kovacs A (1983) Shore ice ride-up and pile-up features, Part I: Alaska's Beaufort Sea coast. US Army Cold Regions Res Eng Lab, Hanover, NH. CRREL Report 83-9, p 59

Kowalik Z (1984) Storm surges in the Beaufort and Chukchi Seas. J Geophys Res 89(C):10,570-10,578

Leffingwell EK (1919) The Canning River Region Northern Alaska. US Geol Surv Prof Pap 109, p 249

Lewellen RI (1970) Permafrost erosion along the Beaufort Sea coast. University of Denver, Denver, p 25

Lewellen RI (1972) Studies on fluvial environments, Arctic Plain Province, northern Alaska. Copyrighted and published by the author, vol I and II, p 282

Lewellen RI (1977) A study of Beaufort Sea coastal erosion, northern Alaska. In: Environmental assessment of the Alaskan Continental Shelf. US National Oceanic and Atmospheric Administration. Ann Rep Principal Investigators 15:491-527

Lynch AH, Cassano EN, Lestak L, Cassano JJ (2003) Case studies of high wind events in Barrow, Alaska: climatological context and development processes. Mont Wea Rev 131:719-732

MacCarthy GR (1953) Recent changes in the shoreline near Point Barrow Alaska. Arctic 6:44-51

Macdonald RW, Naidu AS, Yunker MB, Gobeil C (2003) The Beaufort Sea: distribution sources, variability and burial of carbon. In: Stein R, Macdonald RW (eds) The Organic Carbon Cycle in the Arctic Ocean. Springer, Berlin Heidelberg New York, pp 177-192 
Mackay JR (1986) Fifty years (1935-1985) of coastal retreat and shoreface variations west of Tuktoyaktuk, District of Mackenzie. In: Current research. Part A, Geol Surv Can Pap 86-1A, pp $727-735$

Manley WF (2004) Spatial analysis of coastal erosion over five decades near Barrow, Alaska. 34th Arctic Workshop, 11-13 March 2004, Boulder (abstract)

Naidu AS, Mowatt TC (1975) Depositional environments and sediment characteristics of the Colville and adjacent deltas, northern arctic Alaska. In: Bousard MLS (ed) Deltas: models for subsurface exploration. Houston Geol Soc, Houston, pp 283-309

Naidu AS, Mowatt TC, Rawlinson SE, Weiss HV (1984) Sediment characteristics of the lagoons of the Alaskan Beaufort Sea coast and the evolution of Simpson Lagoon. In: Barnes PW, Schell DM, Reimnitz E (eds) The Alaskan Beaufort Sea: ecosystems and environments, Orlando, Florida. Academic Press Inc., New York, pp 275-292

Naidu AS, Finney BP, Baskaran M (1999) ${ }^{210} \mathrm{~Pb}$ - and ${ }^{137} \mathrm{Cs}$-based sediment accumulation rates in inner shelves and coastal lakes of subarctic and arctic Alaska: a synthesis. In: Bruns P, Hass $\mathrm{HC}$ (eds) On the determination of sediment accumulation rates, GeoResearch Forum 5

Ping CL, Michaelson GJ, Kimble JM, Everett LR (2002) Organic carbon stores in Alaskan soils. In: Kimble JM, Lal R, Follet RF (eds) Agricultural practices and policies for carbon sequestration in soil. Lewis Publishers, Boca Raton, pp 485-494

Rachold V, Grigoriev MN, Are FE, Solomon S, Reimnitz E, Kassens H, Antonow M (2000) Coastal erosion vs. riverine sediment discharge in the Arctic Shelf seas. Int J Earth Sci $89: 450-460$

Rachold V, Brown, J, Solomon S (eds) (2002) Arctic coastal dynamics-report of an international workshop. Polar Mar Res 413:103

Rawlinson SE (1993) Surficial geology and morphology of the Alaskan Central Arctic Coastal Plain. Alaska Division Geological and Geophysical Survey, Fairbanks, AK. Report of Investigations $93-11, \mathrm{p} 72$

Reed JC, Sater JE (eds) (1974) The Coast and Shelf of the Beaufort Sea. Arctic Institute of North America, Arlington, p 749

Reimnitz E, Kempema EW (1987) Thirty-four year shore face evolution at a rapidly retreating arctic coastal site. In: Hamilton TD, Galloway JP (eds) Geological studies in Alaska by the U.S. Geological Survey during 1986, US Geol Surv Circ 998:161-164

Reimnitz E, Maurer DK (1979) Effects of storm surges on the Beaufort Sea coast. Arctic 32:329-344

Reimnitz E, Wolf SC (1998) Are North Slope surface alluvial fans pre-Holocene relicts? US Geol Surv Prof Pap 1605, p 9
Reimnitz E, Graves SM, Barnes PW (1988) Beaufort Sea coastal erosion, sediment flux, shoreline evolution, and the erosional shelf profile. US Geol Surv Map I-1182-G, p 22

Reimnitz E, Barnes PW, Harper J (1990) A review of beach nourishment from ice transport of shoreface materials, Beaufort Sea, Alaska. J Coastal Res 6:439-470

Research Planning Inc. (2002) Environmental sensitivity index shoreline classification of the Alaskan Beaufort Sea and Chukchi Sea. Mineral Management Service, Anchorage, AK. OCS Study MMS 2003-006, p 11

Schell DM (1983) Carbon-13 and carbon-14 abundances in Alaskan aquatic organisms: delayed production from peat in arctic food webs. Science 219:1068-1071

Sellmann PV, Brown J, Lewellen RI, McKim HL, Merry CJ (1975) The classification and geomorphic implications of thaw lakes on the Arctic Coastal Plain, Alaska. US Army CRREL Res Rep 344, p 21

Short AD (1975) Offshore bars along the Alaskan Arctic coast. J Geol 83:209-221

Short AD, Coleman JM, Wright LD (1974) Beach dynamics and nearshore morphology of the Beaufort Sea coast. In: Reed JC, Sater JE (eds) The coast and shelf of the Beaufort Sea, pp 477 488

Solomon S, Gareau P (2003) Beaufort Sea coastal mapping and the development of an erosion hazard index. In: Phillips $\mathrm{M}$, Springman SM, Arenson, LU (eds) ICOP 2003 Permafrost: Proceedings of the 8th International Conference on Permafrost. AA Balkema Publishers, Netherlands, pp 1091-1097

Walker HJ (1976) Depositional environments in the Colville River Delta. In: Miller TP (ed) Recent and ancient sedimentary environments in Alaska, Proceedings of the Alaska Geological Society Symposium. Alaska Geol Soc Anchorage, pp C1-C22

Walker HJ (1983) Erosion in a permafrost-dominated delta. In: Permafrost Fourth International Conference Proceedings. National Academy Press, Washington, pp 1344-1349

Walker HJ (1991) Bluff erosion at Barrow and Wainwright, Arctic Alaska. Z Geomorph NF Suppl Bd 81:53-61

Williams JR; Yeend, WE; Carter, LD, Hamilton, TD (1977) Preliminary surficial deposits map of National Petroleum Reserve - Alaska. US Geol Surv Open File Rep 77-868

Wiseman WJ, Coleman JM, Gregory A, Hsu SA, Short AD, Suhayda JN, Walters CD, Wright LD (1973) Alaskan Arctic coastal processes and morphology. Louisiana State Univ., Coastal Studies Inst Tech Rep 149:171

Woodward-Clyde Consultants (1981) Coastal analysis of Alaska and the Northwest Passage. Report for Dome Petroleum Limited by Woodward-Clyde Consultants, Victoria 